\begin{tabular}{cc|c}
\hline Tar. Bil. Der. & Tarm Bilimleri Dergisi & Journal of Agricultural Sciences \\
& $\begin{array}{c}\text { Dergi web sayfası: } \\
\text { www.agri.ankara.edu.tr/dergi }\end{array}$ & Journal homepage: \\
& www.agri.ankara.edu.tr/journal
\end{tabular}

\title{
Genomic Variability and Recombination Analysis of Grapevine leafroll- associated virus-1 Isolates from Turkey
}

\author{
Eminur ELÇía \\ ${ }^{a}$ Niğde Ömer Halisdemir University, Faculty of Agricultural Sciences and Technologies, Department of Plant Production and Technologies, \\ 51240, Niğde, TURKEY
}

\section{ARTICLE INFO}

Research Article

DOI: 10.15832 /ankutbd.402162

Corresponding Author: Eminur ELÇI, E-mail: eminur@gmail.com, Tel: +90 (534) 5931522

Received: 06 March 2018, Received in Revised Form: 04 July 2018, Accepted: 08 August 2018

\begin{abstract}
Grapevine leafroll-associated virus-1 (GLRaV-1), one of the causal agents of Grapevine leafroll disease (GLRD), is one of the most important viral diseases of grapevine worldwide. In this study, the prevalence of GLRaV-1, genetic variation and recombination events among GLRaV-1 isolates in Turkey were investigated. Initially, 197 grapevine samples from different provinces of the country were serologically tested. Of the total samples, 109 (55.32\%) were identified as GLRaV-1 infected. Subsequently, 9 samples representing different geographic distribution were selected for further sequence analysis of the heat-shock protein 70 homolog (HSP70h), open reading frame 9 (p24), coat protein (CP) and coat protein duplicate $2(\mathrm{CPd} 2)$. Among the four gene regions, $\mathrm{CPd} 2$ was found the most divergent region while HSP70h gene exhibited the lowest genetic diversity. The phylogenetic analysis of four genomic regions including GenBank records clustered all variants in two major groups and grouped Turkish isolates mostly together. However, the isolate clusters were not correlated to their geographic origin. Furthermore, several putative recombination events were detected with trace to moderate evidence support of algorithms implemented in Recombination Detection Program (RDP). Taken together, the results provide a better understanding on genetic variation of Turkish GLRaV-1 isolates in the country and worldwide and can help to improve sanitation of propagated material programs for the grape growers.
\end{abstract}

Keywords: Vitis vinifera L.; CP; CPd2; p24; HSP70h; Genetic variation

(C) Ankara Üniversitesi Ziraat Fakültesi

\section{Introduction}

Grapevine (Vitis sp.) is one of the most widely grown woody crops worldwide. Turkey produces 4.175.356 tons of grapes and ranks the $6^{\text {th }}$ in production after China, USA, Italy, Spain and France (FAOSTAT 2014). Many viruses can cause damages to grapevine in the form of yield losses, short survival life and quality decreases. Among the grapevine virus diseases, the most widespread and economically destructive one is grapevine leafroll disease (GLRD), which was first described in the mid- $19^{\text {th }}$ century. The main symptoms of GLRD include, leaf rolling, interveinal reddening of the leaves and reduced pigmentation in red-fruited cultivars, leaf chlorosis in white-fruited cultivars and reduced yields, lower Brix and uneven ripening. GLRD effects on fruits are poor maturation of berries, lower Brix content and yield, and reduced wine pigmentation. The phloem limited filamentous- 
shape viruses associated with that disease are named as Grapevine leafroll associated viruses (GLRaVs). They are represented by the species GLRaV-1, -2 , -3 and -4 and recently, GLRaV-5, -6, -9, GLRaV$\mathrm{Pr}$, GLRaV-De, and GLRaV-Car were recognized as strains of GLRaV-4 (Martelli et al 2012). All these viruses belong to the family Closteroviridae, with GLRaV-2 belonging to the genus Closterovirus, GLRaV-7 belongs to a newly proposed genus Velarivirus and the other GLRaVs to the genus Ampelovirus (Martelli 2014).

The GLRaV-1 genome has a positive $(+)$ sense single-stranded (ss) RNA genome $19.5 \mathrm{~kb}$ in size organized into ten major open reading frames (ORFs) and those frames encoding proteins have different functions. A putative RNA helicase is encoded by ORF-1a and an RNA-dependent RNA polymerase is encoded by ORF-1b. Other ORFs encodes one hydrophobic protein, capsid protein (CP), a HSP70 family of heat shock proteinshomologue (HSP70h), a HSP90-like protein, two diverged CP gene copies (CPd1 and CPd2) and two more proteins. Moreover, GLRaV-1 is the only one among the GLRaVs which includes two diverged CP gene copies (Fazeli \& Rezaian 2000).

Understanding the genome of the species, variants of the virus and genetic diversity of viral populations are of significant importance for epidemiological studies and certification testing to prevent its spread and improve efficient control strategies. RNA viruses, such as GLRaVs, have high ratio of genetic diversity due to an error-prone replication with high mutation rates; therefore, the evolutionary processes which allow them to spread throughout the species need to be clarified (Fazeli \& Rezaian 2000). Although GLRaV-1 is a common virus infecting grapevine plants worldwide, limited information is available in literature about the genomic variability and molecular evolution of GLRaV-1 (Little et al 2001; Kominek et al 2005; Alabi et al 2011; Predajna et al 2013; Cseh et al 2013; Fan et al 2015).

GLRaV-1 has been detected in Turkey since 1997 (Çağlayan 1997; Köklü et al 1998; Çı̆̆sar et al 2002; Akbaş et al 2007; 2009; Değer et al 2015; Önder 2016) however the nucleotide sequence variation between isolates was unknown. Therefore, genomic variability and recombination events of Grapevine leafroll-associated virus-1 isolates in Turkey were evaluated through the sequence analysis of four different genomic regions of the virus. For this purpose, the HSP70h, CP, ORF9 (p24) and CPd2 genes of GLRaV-1 were amplified, sequenced and possible recombination events were investigated.

\section{Materials and Methods}

Grapevine leaves showing suspicious GLRD symptoms were collected from Hatay, Gaziantep and Tekirdağ provinces of Turkey during autumn 2015. In total, 197 grapevine samples, cvs. Antep karas1, Pafu, Kalecik which are the local varieties and cv. Syrah, were collected and the leaves were stored at $20{ }^{\circ} \mathrm{C}$ until use.

The collected samples were analyzed by a double antibody sandwich, enzyme-linked immune sorbent assay (DAS-ELISA) using the Bioreba's commercial kit (Bioreba, Switzerland) based on Clark \& Adams (1977) method. BIOTEK-EL800 spectrophotometer (BioTek, USA) was used for measurement of absorbance values at $405 \mathrm{~nm}$. Assays were done following the manufacturers' instructions.

The RNAs were isolated and purified from leaf tissues by a commercial RNA isolation kit following the manufacturer's instructions (RNeasy Plant Mini Kit, Qiagen Sci., Germany) and their yield and quality were estimated by a NanoDrop spectrophotometer (NanoDrop2000c, Thermo Sci., USA).

The cDNA was synthesized based on the twostep protocol and used as a template for PCR analysis. For reverse transcription of total RNAs, random hexamer primers and the cDNA synthesis kit were used (SuperScript ${ }^{\mathrm{TM}}$ Choice System for cDNA Synthesis, Thermo Sci., USA). The PCR was conducted with $2 \mu \mathrm{L}$ of template, $0.5 \mu \mathrm{L}$ of 10 $\mathrm{mM}$ dNTPs, $1.5 \mu \mathrm{L}$ of $25 \mathrm{mM} \mathrm{MgCl}_{2}, 2.5 \mu \mathrm{L}$ of $5 \mathrm{x}$ 
green reaction buffer and $0.5 \mu \mathrm{L}$ of $10 \mu \mathrm{M}$ of each specific primers for $\mathrm{HSP} 70 \mathrm{~h}, \mathrm{p} 24, \mathrm{CP}, \mathrm{CPd} 2$ genes of GLRaV-1 (Alabi et al 2011) adding with 0.2 $\mu \mathrm{L}$ of 5 units $\mu \mathrm{L}^{-1}$ Taq DNA polymerase (GoTaq ${ }^{\circledR}$ DNA Polymerase, Promega Corp., USA). PCR amplifications were performed as: denaturation at $94{ }^{\circ} \mathrm{C}$ for $5 \mathrm{~min}$; 40 cycles of annealing at $94{ }^{\circ} \mathrm{C}$ for $30 \mathrm{~s}, 55^{\circ} \mathrm{C}$ for $45 \mathrm{~s}$, and $72{ }^{\circ} \mathrm{C}$ for $1 \mathrm{~min}$; extension at $72{ }^{\circ} \mathrm{C}$ for $10 \mathrm{~min}$.

The PCR amplicons were sequenced in both directions (forward and reverse) by an Automated Genetic Analyzer (ABI3730, MedSanTek Company, Turkey). The obtained nucleotide sequences were analyzed by the program Molecular Evolutionary Genetics Analysis (software MEGA 6.06, Tamura et al 2013). BLASTn and BLASTx modules were used to determine nucleotide and amino acid identities of GLRaV-1 Turkish isolates to reference isolate (Nucleotide ID: Acc. No. NC016509, Protein ID: Acc. No. YP004940644 (Hsp70), YP004940646 (CP), YP004940648 (CPd2), YP004940650 (p24)) at BLAST on NCBI.

Phylogenetic analysis was conducted on the 4 different partial gene regions of GLRaV-1. The GenBank (NCBI) nucleotides of different GLRaV-1 isolates were included in the analysis. Multiple nucleotide and amino acid alignments were performed with CLUSTAL W (Larkin et al 2007) and the phylogenetic tree was drawn based on the neighbor-joining method implemented in the program MEGA 6.06 (Tamura et al 2013). The Bootstrap analysis was performed with 1000 replications. Little cherry virus-2 (LCV-2, Acc.No. NC005065) was used as out-group.

The aligned nucleotides of the isolates were analyzed for the recombination events using seven recombination detection algorithms in Recombination Detection Program (RDP) version 4.16 (Martin et al 2015). Sequences were masked to be sure for optimal recombination detection before algorithm analysis. "Sequences are linear" option and Bonferroni-corrected $\mathrm{P}$ value cut-off of 0.05 were selected.

\section{Results and Discussion}

According to DAS-ELISA results, 109 out of 197 collected from Hatay (61 out of 107 samples), Gaziantep (23 out of 46 samples) and Tekirdağ (25 out of 44 samples) grapevine samples were found to be infected by GLRaV-1. Hatay and Gaziantep are Southeast regions of the country and rather far from the third region, Tekirdağ. Although they distantly located, they exhibited approximately same level of the virus prevalence. To date, there are several studies on GLRaV-1 incidence in grapevine growing areas of Turkey. Özaslan \& Y1lmaz (1985) reported GLRaV-1 as a common virus in some provinces and Çağlayan (1997) found GLRaV-1 always as mixed infection with GVA in Hatay province of Turkey. Moreover, GLRaV-1 was found to be the most common virus in Central Anatolia with the infection rate of $8.36 \%$ by DAS-ELISA (Akbaş et al 2007). Recently another survey was conducted in Eastern Mediterranean Region of Turkey and the most common virus was found to be GLRaV-1 with the infection rate of $55.56 \%$ followed by GLRaV-4 (43.14\%), GLRaV-2 (15.69\%) and GLRaV-3 $(12.42 \%)$ by RT-PCR analysis (Değer et al 2015). Önder (2016) studied on prevalence of GLRaVs (GLRaV-1， GLRaV-2， GLRaV-3， GLRaV-4, GLRaV-5, GLRaV-6, GLRaV-7, GLRaV-9, GLRaVPr and GLRaV-De) at Manisa, Denizli, İzmir, Aydın and Uşak provinces and reported that 133 out of 424 samples were infected at least by one GLRaVs and regardless the mixed infections, GLRaV-Pr was the most widespread one with $12 \%$ infection rate which followed by GLRaV-De (12\%), GLRaV-3 (8.5\%), GLRaV-2 (2.8\%), GLRaV-4 (2.4\%), GLRaV-9 (0.9\%), GLRaV-1 (0.5\%), GLRaV-5 (0.2\%) and GLRaV-7 (0.2\%), respectively. Our results are in accordance with previously reported RT-PCR analysis results on grapevine plants infected with GLRD. The high incidence of this virus and poor sanitation conditions for grapevines were indicated in Turkey. The reason of such a high incidence of this virus can be due to vector transmissions, since most samples were infested by mealybugs, a vector responsible for transmission of this virus (Sforza et 
al 2003). Another reason could be the usage of uncertified materials (scions, rootstocks etc.).

Among DAS-ELISA positive samples for GLRaV-1, nine representative isolates were chosen according to their geographical region and cultivar for genetic analysis. All these isolates were successfully amplified for four genomic regions of GLRaV-1 based on RT-PCR assays using with specific primers for $\mathrm{CP}, \mathrm{CPd} 2$ and $\mathrm{p} 24$, HSP70h genes with amplification product sizes 734 bp, 398 bp, 634 bp, of 540 bp, respectively.

All obtained PCR amplicons were purified and sequence analysis was done. After nucleotide assembly, the sequences of each RNA segment were deposited in GenBank with accession numbers of KU362237-KU362263 and KU362270KU362278. Based on the BLAST analysis, the nucleotide and amino acid sequence identities of the nine Turkish GLRaV-1 isolates to reference isolate ranged from 79 to $94 \%$ and from 75 to $96 \%$, respectively. The CP sequences obtained in this study showed the nucleotide identities ranged from 85 to $87 \%$; whereas amino acid identities ranged from 93 to $96 \%$. For CPd 2 sequences, it ranged from 78 to $80 \%$ and from 75 to $79 \%$, respectively. The level of nucleotide and amino acid sequence identities for p24 gene ranged between $79-82 \%$ and $80-84 \%$, respectively. Only the isolate 141 showed highest identity among them ( $94 \%$ nt identity and $93 \%$ a.a. identity). Based on HSP70h gene sequence analysis nucleotide identities ranged from 82 to $84 \%$ and amino acid identities ranged between $90-91 \%$ (Table 1). The overall mean distance values of CP, CPd2, p24 and Hsp70h regions' nucleotides were 0.044, $0.065,0.110$ and 0.049 , respectively. Moreover, the overall mean value of nucleotide diversity for 4 gene regions were $0.067,0.110,0.081$ and 0.142 . The observed most divergent region was $\mathrm{CPd} 2$ while the lowest region was HSP70h. These findings confirm two previous studies reported that GLRaV-1 genes have a high genetic variation and the CPd2 gene is the most variable gene (Little et al 2001; Alabi et al 2011).
Table 1- Nucleotide and amino acid identities of four different genes of Grapevine leafroll-associated virus-1 Turkish isolates to reference isolate (Nucleotide ID: Acc. No. NC016509, Protein ID: Acc. No. YP004940644 (Hsp70), YP004940646 (CP), YP004940648 (CPd2), YP004940650 (p24)) based on BLAST (blastn and blastx) analyses

\begin{tabular}{|c|c|c|c|c|}
\hline $\begin{array}{l}\text { Isolate } \\
\text { name }\end{array}$ & Gene & $\begin{array}{c}\text { Accession } \\
\text { number }\end{array}$ & $\begin{array}{c}\text { Nucleotide } \\
\text { identity } \\
(\%)\end{array}$ & $\begin{array}{c}\text { Amino acid } \\
\text { identity } \\
(\%)\end{array}$ \\
\hline 81 & Hsp70h & KU362237 & 83 & 91 \\
\hline 86 & Hsp70h & KU362238 & 83 & 91 \\
\hline 89 & Hsp70h & KU362239 & 82 & 90 \\
\hline 102 & Hsp70h & KU362240 & 82 & 91 \\
\hline 126 & Hsp70h & KU362241 & 82 & 90 \\
\hline 129 & Hsp70h & KU362242 & 83 & 91 \\
\hline 130 & Hsp70h & KU362243 & 83 & 91 \\
\hline 141 & Hsp70h & KU362244 & 84 & 91 \\
\hline 147 & Hsp70h & KU362245 & 83 & 91 \\
\hline 81 & p24 & KU362246 & 82 & 83 \\
\hline 86 & $\mathrm{p} 24$ & KU362247 & 81 & 81 \\
\hline 89 & p24 & KU362248 & 81 & 84 \\
\hline 102 & p24 & KU362249 & 81 & 83 \\
\hline 126 & p24 & KU362250 & 80 & 83 \\
\hline 129 & p24 & KU362251 & 80 & 83 \\
\hline 130 & p24 & KU362252 & 79 & 80 \\
\hline 141 & $\mathrm{p} 24$ & KU362253 & 94 & 93 \\
\hline 147 & p24 & KU362254 & 80 & 80 \\
\hline 81 & $\mathrm{CPd} 2$ & KU362255 & 79 & 75 \\
\hline 86 & $\mathrm{CPd} 2$ & KU362256 & 80 & 77 \\
\hline 89 & $\mathrm{CPd} 2$ & KU362257 & 79 & 75 \\
\hline 102 & $\mathrm{CPd} 2$ & KU362258 & 78 & 75 \\
\hline 126 & $\mathrm{CPd} 2$ & KU362259 & 80 & 79 \\
\hline 129 & $\mathrm{CPd} 2$ & KU362260 & 80 & 78 \\
\hline 130 & $\mathrm{CPd} 2$ & KU362261 & 80 & 78 \\
\hline 141 & $\mathrm{CPd} 2$ & KU362262 & 80 & 77 \\
\hline 147 & $\mathrm{CPd} 2$ & KU362263 & 80 & 79 \\
\hline 81 & $\mathrm{CP}$ & KU362270 & 87 & 96 \\
\hline 86 & $\mathrm{CP}$ & KU362271 & 87 & 93 \\
\hline 89 & $\mathrm{CP}$ & KU362272 & 86 & 94 \\
\hline 102 & $\mathrm{CP}$ & KU362273 & 87 & 96 \\
\hline 126 & $\mathrm{CP}$ & KU362274 & 88 & 96 \\
\hline 129 & $\mathrm{CP}$ & KU362275 & 86 & 96 \\
\hline 130 & $\mathrm{CP}$ & KU362276 & 85 & 95 \\
\hline 141 & $\mathrm{CP}$ & KU362277 & 88 & 95 \\
\hline 147 & $\mathrm{CP}$ & KU362278 & 85 & 95 \\
\hline
\end{tabular}

81, 86, 89, cv. Antep Karasi-Hatay; 102, 126, cv. Pafu-Hatay; 129, 130, cv. Antep Karas1-Gaziantep, 141, cv. Kalecik-Tekirdağ; 147, cv. Syrah-Tekirdăg 
Phylogenetic relationships among Turkish GLRaV-1 isolates were determined for four gene regions and compared with the other isolates deposited in GenBank from different countries such as California, Washington and New York-USA, Portugal, Slovenia, Czech Republic, Iran, Hungary, China, Poland, India, Poland, Chile, Canada, Italy. There are a few studies on genetic diversity of GLRaV-1 from Europe. Kominek et al (2005) reported that GLRaV-1 can be grouped into two sequence variants based on sequences derived from the HSP70h gene of eight isolates from Slovakia and the Czech Republic. Also, from partial nucleotide sequences of this gene, the authors reported that GLRaV-1 isolates consisted of two variant groups, tentatively designated as groups A (North America and Australia) and E (Europe). However, more recent data from the USA supported the grouping of a wider range of GLRaV-1 isolates into three main variant groups based on the p24 and HSP70h gene sequences (Alabi et al 2011).

In this study, the 54 partial $\mathrm{CP}$ gene sequences (15 from China, 13 from USA, 13 from Portugal, 9 from Turkey, 1 from Iran, 1 from Poland, 1 from Canada and 1 as reference isolate (RefSeq) were analyzed and segregated into two major groups. Group 1 includes most of the isolates from Portugal, China, USA, Canada, Poland, and Iran additional to Turkish isolates. Turkish GLRaV1 CP isolates were closely clustered in the same subgroup of Group 1. Group 2 includes only some of the isolates from China and USA (Figure 1a). Based on the dendrogram, there is no distinct separation within and between the isolates collected from the same geographical conditions. Here, it can be concluded that there is no high degree of variation at the $\mathrm{CP}$ gene of analyzed Turkish GLRaV1 isolates. In accordance with other studies (Alabi et al 2011; Esteves et al 2013) the results of phylogenetic analysis did not show a clear correlation between phylogeny and geographical origin. The most common GLRaV-1 variants obtained from CP gene sequences belonged to Group I (Esteves et al 2013) whereas the majority of Chinese GLRaV-1 variants belong to Group II (Fan et al 2015). They reported that natural selection rather than a random process has led to the evolution of CP gene sequence variants in Group II. For the CPd2 analysis; 23 isolates from USA, 9 from Turkey, 1 from Poland, 1 from Iran, 1 from Chile, and 1 RefSeq were used. Two main groups were obtained and the Turkish isolates were clustered into Group 2. Some of the Californian isolates (CA3, CA6, CA10, CA11, CA16, CA18, CA20) were found highly similar to Turkish isolates with high bootstrap values. The GenBank sequences obtained from Poland, Iran and most of the American isolates were clustered into Group 1 with reference sequence (NC016509) while none of the Turkish isolates were clustered there (Figure 1b).

Phylogenetic analyses of 45 sequences of p24 (USA: 32, India: 2, Iran: 1, Turkey: 9, RefSeq: 1) resulted into two main groups with three subgroups. The Turkish isolates were mostly clustered together into group 1 and showed highest similarity with three Californian (CA21, CA2, CA6) and one Iranian (IR-S7) isolates. The isolate 141p24 which was extracted from a local cultivar, Kalecik, was found highly similar to RefSeq (NC016509) isolate. The out-group control LCV-2 was distinctly separated from all the isolates as expected (Figure 1c). Global HSP70h-specific sequences of GLRaV-1 (Total 51; USA: 19, Slovenia: 11, Portugal: 6, Czech Republic: 2, Hungary: 1, Iran: 1, Italy: 1, Turkey: 9, reference isolate (RefSeq):1) segregated into two major phylogroups with two subgroups. Group 1 consists of American, Portugal, Slovenian, Czech, Iranian and Turkish isolates while Group 2 consists of Slovenian, American and Hungarian isolates. Turkish isolates were clearly separated and clustered together in the same group (Figure 1d). According to Kominek et al (2005) this cluster can be separated into two groups that were designated as groups A and E however Alabi et al (2011) reported three distinct variant groups and they could not found any evidence for precisely defined geographical structuring of GLRaV-1 isolates among the three groups. Our phylogenetic analysis of GLRaV-1 HSP70h gene is corresponded to the results of Kominek et al (2005) and Cseh et al (2013) regarding the number of the phylogroups however no correlation was found for 

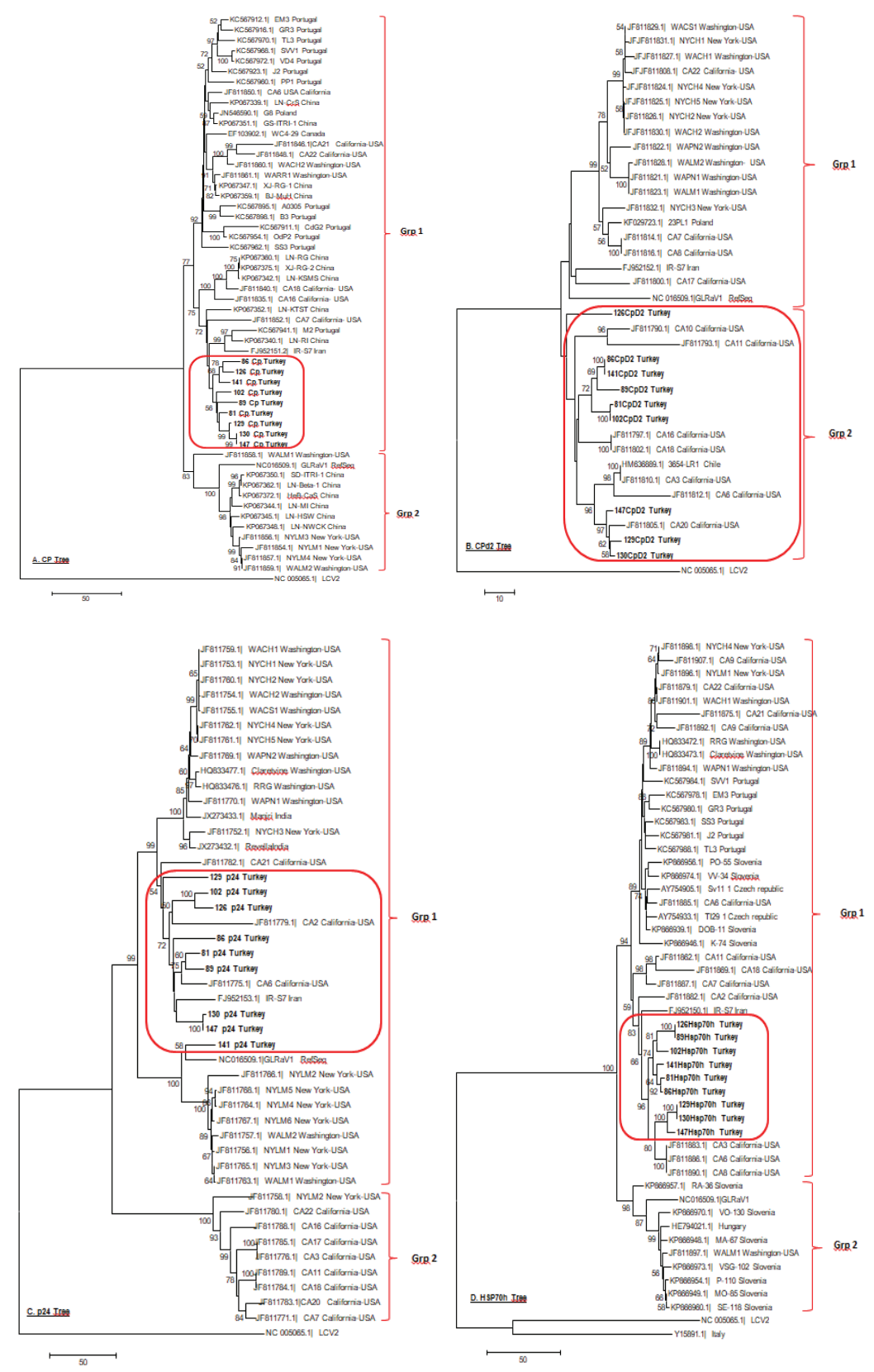

Figure 1- Phylogenetic analysis of Grapevine leafroll-associated virus 1 isolates by neighbor-joining method based on nucleotide diversity of the a, coat protein (CP); b, coat protein duplicate 2 (CPd2); c, movement protein (p24); d, heat shock protein 70 homologue (HSP70h). The sequences obtained in this study are marked in bold and their clusters are shown in red circle. Little cherry virus-2 (LCV-2) was used as outgroup control. Bootstrap analysis was done with 1000 replications and the values more than 50 are given at the branch nodes 
geographical structure same as Alabi et al (2011). The cell to cell movement protein, which is HSP70 gene product, has highly conserved sequence among Closteroviridae family members (Dolja et al 1994). Based on the phylogenetic analysis in this study, the lowest divergent genomic region was also detected as HSP70h region of GLRaV1 among the analyzed gene sequences. GLRaV-1 sequences of CPd2-derived phylogenetic trees constructed with American isolates confirmed recombination event possibilities in this gene. Therefore, it is suggested to use both p 24 and HSP70h genes for the significant analysis of the phylogeny of GLRaV-1 variants (Alabi et al 2011).

Recombination analysis of the four gene sequences (the HSP70h, CP, CPd2, and p24) has been performed and several putative recombination events with moderate support were detected in the $\mathrm{CP}, \mathrm{CPd} 2$, and $\mathrm{p} 24$ regions (Table 2). Recombination events in RNA viruses are reported as a powerful inducement for generating new variants (SimonLoriere \& Holmes 2011). No significant recombination events in the HSP70 gene (9 from this study and 22 from GenBank) were detected by any of software implemented in RDP program. Recombination analysis in the p24 region ( 9 from this study and 22 from GenBank) have resulted in detection of 3 putative recombination events and the event 2 and 3 were included also in Turkish isolates, 141 (GenBank accession no: KU362253), 102
(KU362249) and 129 (KU362251). The putative recombination event 2 involved 102 (KU362249) as potential parent and the GenBank isolate CA3 (JF811776) was used to infer the unknown parent. This recombination event was detected in 8 isolates 141, NJ016509, JF811768, JF811767, JF811766, JF811765, and JF811764. Trace evidence of the same recombination event was also detected in the GenBank records, NJ016509, JF811763, and JF811756. Recombination position of the event 2 was depicted at Figure 2. It is noticeable that based on recombinant sequence of $\mathrm{p} 24$, the Turkish isolate 141 placed close to sequence of NYR isolates rather than grouping with the remaining Turkish isolates. Recombination event 3 were found in 8 isolates including a Turkish isolate 129 as major parent but this recombination event was supported with only one program (SiSican). One putative recombination event was detected in $\mathrm{CP}$ sequences generating three putative recombinant sequences (JF811846CA2, JF811848-CA2, and JF811860-WAC). The event involved KC567911-CdG as minor parental sequences and no major parents were identified among the sequences examined. With respect to $\mathrm{CPd} 2$ gene, 3 recombination events detected and none of them involved Turkish isolates. The recombination is an important evolutionary trait of Closteroviridae family members (Karasev 2000). Thereby, RNA recombinations play a significant role in this virus evolution and variation. Putative recombination events were also previously found in

Table 2- Recombination events detected in p24 gene, CP gene and CPd2 gene of Grapevine leafrollassociated virus-1 by RDP program

\begin{tabular}{|c|c|c|c|c|c|c|c|c|c|c|c|c|}
\hline \multirow{2}{*}{$\begin{array}{l}\text { Gene } \\
\text { name }\end{array}$} & \multirow{2}{*}{$\begin{array}{l}\text { Event } \\
\text { number }\end{array}$} & \multirow{2}{*}{$\begin{array}{c}\text { Found } \\
\text { in }\end{array}$} & \multirow{2}{*}{ Recombination } & \multirow{2}{*}{ Major parent } & \multirow{2}{*}{ Minor parent } & \multicolumn{7}{|c|}{ Detection methods } \\
\hline & & & & & & $R$ & $G$ & $B$ & $M$ & $C$ & $S$ & $T$ \\
\hline \multirow{3}{*}{ p24 } & 1 & 1 & JF811766.1|NYL & JF8117 & Unknown & + & + & - & + & + & - & + \\
\hline & 2 & 10 & JF811757.1|WAL & $102 \_\mathrm{p} 2$ & Unknown & + & - & - & - & - & + & - \\
\hline & 3 & 8 & FJ952153.1|IR- & $129 \_\mathrm{p} 2$ & Unknown & - & - & - & + & - & - & - \\
\hline \multirow[t]{2}{*}{$\mathrm{CP}$} & 1 & 3 & JF811846.1|CA2 & Unknown & KC567911.1|CdG & - & - & - & + & + & + & + \\
\hline & 1 & 2 & JF811802.1|CA1 & JF8118 & JF811812.1|CA6 & - & - & - & + & - & + & - \\
\hline \multirow[t]{2}{*}{ CPd2 } & 2 & 1 & JF811800.1|CA1 & JF811832.1|NYC & 89CpD2 & - & - & - & + & - & - & - \\
\hline & 3 & 1 & JF811812.1|CA6 & 86CpD2 & JF811832.1|NYC & - & - & - & + & + & + & - \\
\hline
\end{tabular}

Tarım Bilimleri Dergisi - Journal of Agricultural Sciences

25 (2019) 319-327 


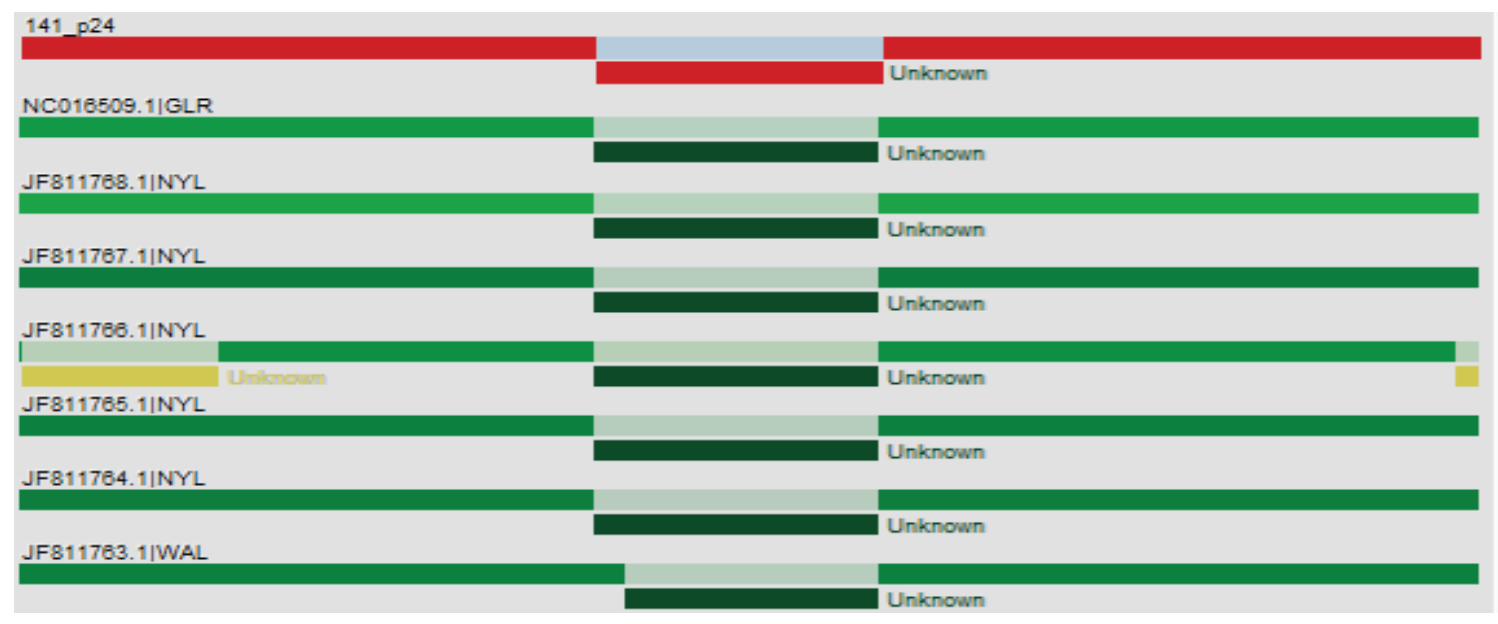

Figure 2- Recombination events of p24 gene of Grapevine leafroll-associated virus-1 detected by RDP program. Two events were displayed by RDP program. Event 1 is shown in yellow. Event 2 displayed with dark green and red for Turkish isolate 141

HSP70h gene, CP gene and p24 sequences but not in the CPd2 gene (Alabi et al 2011). More recently 3 new putative recombination events were detected in CP gene of Chinese GLRaV-1 isolates (Fan et al 2015).

\section{Conclusions}

In conclusion, a high frequency of GLRaV-1 in grapevines was detected. Taken together the nucleotide comparisons, phylogenetic and recombination analysis, the results indicate there is no distinct grouping according to geographic source although samples were taken from distantly located regions. This finding indicates dissemination of the virus occurs via propagation materials transfer and emphasizes use of virus-free plant material in preventing the dissemination of this virus.

\section{Acknowledgements}

The author would like to thank Prof. Dr. Kadriye ÇAĞLAYAN, Prof. Dr. Mona GAZEL from Mustafa Kemal University for plant material providing and Dr. Kahraman GÜRCAN from Erciyes University for recombination analysis.

\section{References}

Akbaş B, Kunter B \& Ilhan D (2007). Occurrence and distribution of grapevine leafroll-associated viruses 1, 2, 3 and 7 in Turkey. Journal of Phytopathology 155: $122-124$

Akbaş B, Kunter B \& Ilhan D (2009). Influence of leafroll on local grapevine cultivars in agroecological conditions of Central Anatolia region. Horticulture Science (Prague) 36: 97-104

Alabi O, Rwahnih J, Karthikeyan M A, Poojari G, Fuchs S, Rowhani M \& Naidu A (2011). Grapevine leafrollassociated virus 1 occurs as genetically diverse populations. Phytopathology 101: 1446-1456

Çağlayan K (1997). Incidence of grapevine leafroll, grapevine virus A and tomato black ring virus in the vineyards of Hatay province. The Journal of Turkish Phytopathology 26: 121-129

Çı̆̆sar I, Digiaro M \& Martelli G P (2002). Sanitary status of grapevines in south-eastern and central Anatolia (Turkey). Bulletin EPPO 32: 471-475

Clark M F \& Adams A N (1977). Characteristics of the microplate method of enzyme-linked immunosorbent assay for the detection of plant viruses. Journal of General Virology 34: 475-483

Cseh E, Takacs P A, Gáborjányi R, Palkovics L \& Kocsis L (2013). RT-PCR analysis and evolutionary relationship of some Hungarian grapevine leafroll 
associated virus 1 and 3 isolates. American Journal of Plant Science 4: 2006-2010

Değer E, Gazel M \& Çağlayan K (2015). Current status of grapevine leafroll associated viruses in Hatay and Gaziantep provinces in Turkey. In: Proceedings of the $18^{\text {th }}$ Congress of the International Council for the Study of Virus and Virus-like Diseases of the Grapevine (ICVG), 7-11 September, Ankara, Turkey, pp. 164-165

Dolja V K, Karasev K \& Koonin E V (1994). Molecular biology and evolution of Closteroviruses: Sophisticated build-up of large RNA genomes. Annual Review of Phytopathology 32: 261-285

Esteves F, Teixeira Santos M, Eiras-Dias J E \& Fonseca F (2013). Molecular data mining to improve antibodybased detection of grapevine leafroll-associated virus-1 (GLRaV-1). Journal of Virology Methods 194: $258-270$

Fan X, Hong N, Dong Y, Ma Y, Zhang Z P, Ren F, Hu G, Zhou J \& Wang G (2015). Genetic diversity and recombination analysis of grapevine leafrollassociated virus 1 from China. Archives of Virology 160: $1669-1678$

FAOSTAT (2014). FAOSTAT. Food and agriculture organization of the united nations. Retrieved in April 2016 from http://faostat.fao.org/default.aspx

Fazeli C F \& Rezaian M A (2000). Nucleotide sequence and organization of ten open reading frames in the genome of Grapevine leafroll-associated virus 1 and identification of three subgenomic RNAs. Journal of General Virology 81(3): 605-615

Karasev A V (2000). Genetic diversity and evolution of Closteroviruses. Annual Review of Phytopathology 38: 293-324

Kominek P, Glasa M \& Bryxiová M (2005). Analysis of the molecular variability of grapevine leafrollassociated virus 1 reveals the presence of two distinct virus groups and their mixed occurrence in grapevines. Virus Genes 31: 247-255

Köklü G, Digiaro M \& Savino V (1998). A survey of grapevine viruses in Turkish Thrace. Phytopathologia Mediterranea 37: 140-142

Larkin M A, Blackshields G, Brown N P, Chenna R, McGettigan P A \& McWilliam (2007). Clustal W and
Clustal X version 2.0. Bioinformatics 23(21): 29472948

Little A, Fazeli C F \& Rezaian M A (2001). Hypervariable genes in grapevine leafroll- associated virus 1. Virus Research 80: 109-116

Martelli G P (2014). Directory of virus and virus-like diseases of the grapevine and their agents. Journal of Plant Pathology 96: 105-120

Martelli G P, Agranovsky A A, Al Rwahnih M, Dolja V V, Dovas C I \& Fuchs M (2012). Taxonomic revision of the family Closteroviridae with special reference to the grapevine leafroll-associated members of the genus Ampelovirus and the putative species unassigned to the family. Journal of Plant Pathology 94: 7-19

Martin D P, Murrell B, Golden M, Khoosal A \& Muhire B (2015). RDP4: Detection and analysis of recombination patterns in virus genomes. Virus Evolution 1(1): vev003

Önder S (2016). Ege Bölgesi bağlarında asma yaprak kıvrılma hastalığı ile ilişkili virüslerin tanılanması ve karakterizasyonu/Detection and characterization of grapevine leafroll-associated viruses (GLRaVs) in Aegean vineyards. PhD Thesis, Ege University, TR

Özaslan M \& Yilmaz M A (1985). Adana Tarsus Gaziantep Şanlıurfa ve Adıyaman bölgelerinde yetiştirilen bağlara zarar veren virüs hastalıkları. In: Proceedings of the VII. Türkiye Fitopatoloji Kongresi, 26-29 Eylül, Turkey, pp. 306-312

Predajna L, Gaziova A, Holovičová E \& Glasa M (2013). Analysis of a short genomic region of grapevine leafroll-associated virus $1(\mathrm{GLRaV}-1)$ reveals the presence of two different molecular groups of isolates in Slovakia. Acta Virology 57(3): 353-356

Sforza R, Boudon-Padieu E \& Grei C (2003). New mealybug species vectoring grapevine leaf roll associated viruses-1 and -3 (GLRaV-1 and -3). European Journal of Plant Pathology 109: 975-981

Simon-Loriere E \& Holmes E C (2011). Why do RNA viruses recombine? Nature Reviews Microbiology 6: $617-626$

Tamura K, Stecher G, Peterson D, Filipski A \& Kumar S (2013). MEGA6: Molecular Evolutionary Genetics Analysis Version 6.0. Molecular Biology Evolution 30(12): 2725-2729 